\section{Oral health programming and its relationship to epidemiology: challenges and opportunities}

\author{
Programação em saúde bucal e sua relação com a \\ epidemiologia: desafios e possibilidades
}

\section{Programación de salud bucal y su relación con la epidemiología: retos y oportunidades}

Samuel Jorge Moysés 1,2

To problematize this attempt, I draw on a critical approach from the 1980s by renowned authors from both areas (planning and epidemiology), in the title of an article asking critically whether there was going to be a "marriage or divorce" between the two disciplines 1 . It is worrisome to this day to read the reasons cited "to explain the failure of health planning in Brazil and the role of epidemiology in this situation" 1 (p. 447). Assuming that the authors were backed by solid arguments when they published the article and that their generic critique of Brazilian public health at that time would fit then-prevailing oral health policy like a glove, an update of that critical analysis is now necessary for the country's current National Oral Health Policy.

It is beyond the scope here to go into detailed aspects of the necessary interfaces between planning and epidemiology in oral health. What is relevant is to comment on the "state-of-the-art" in implementing one of the most challenging and complex moments in planning, namely programming. Researchers, administrators, and clinical teams in oral health services in the SUS all agree that "we are good at diagnosing problems, but not as good at providing solutions", or that we "have plenty of initiatives, but few 'finish-iatives". Such jargon expresses a deeper perception (beyond the surface of daily health services) that objectives, goals, roles, structures, resources, responsi- 
bilities, timelines, indicators, and results are often neglected, leaving an institutional void in their place. Fundamental programmatic principles are being postponed or overlooked, to the detriment of the population's final health outcomes, inexorably missed due to lack of direction.

In the policymaking and policy implementation cycle, the moment of programming is a mode of representation of the complex process involving the construction of a given government decision and its implementation 2 . It thus becomes a social intervention tool, simultaneously a political strategy for building future sustainability and a rationale at the service of governance in the present. It is precisely in programming that we should find the necessary technological application for better use of resources (whether existing ones or those demanded by administrators, clinical teams, and public opinion in general in their agendas for inter-sector disputes). In the particular case of oral health, this application aims to produce epidemiological results or personal care outcomes, with a social impact at the material or immaterial level for the subjects involved.

It will not be necessary to question the political efficacy (thus far nonexistent) of oral health programming in the majority of Brazil's States and Municipalities. At the technical level, we already know that oral health programming adopts an incomplete rationale. An apparently trivial example suffices to back this assertion: a study on programming oral hygiene in children showed that among the 54 public health agencies surveyed (including the Ministry of Health and the Health Departments of Brazil's States and State capitals), the guidelines were inconsistent and conflicting and could be associated with an apparent gap in the scientific evidence 3 . In the $21^{\text {st }}$ century it is apparently impossible to consistently operationalize oral hygiene practices, much less the more complex interventions at the individual and collective levels.

This does not mean to underrate recent efforts at the Federal level, seeking to induce new programmatic positions at the State and $\mathrm{Mu}$ nicipal levels through various "incentives" in the Smiling Brazil program. Such initiatives feature the training materials produced by the Planning System of the Unified National Health System (PlanejaSUS; http://bvsms.saude.gov.br/ bvs/publicacoes/planejaSUS_livro_1a6.pdf) and in oral health the publication Caderno de Atenção Básica (Handbook of Primary Care), no. 17 in 2008 (http://dab.saude.gov.br/portaldab/bib lioteca.php?conteudo=publicacoes $/$ cab17). The Ministry of Health has also played a leading role in oral health surveillance, producing valuable epidemiological information, capable of describ- ing the health situation and unveiling inequalities between distinct populations or regions and their particular needs, as attested by the experience with SBBrasil 20104 . This process makes information and technological resources available for: (a) strengthening organic programming and more precise interventions in health problems; (b) operationalization of the concept of social determination of the health-disease process and its relationship to common protective and/or risk factors; (c) prevention or harm reduction; (d) inter-sector action; (e) actions in the territory; and (f) evidence-based intervention in the form of health promotion operations.

Although such possibilities are powerful (in the sense of the necessary programming for the SUS, it is still disconcerting to find relatively precarious oral health indicators that are agreed on and monitored at the national level, such as "coverage for the first programmed dental visit" and "coverage of collective action for supervised tooth-brushing". This is very little given the current complex programmatic challenges, such as dealing with inequalities based on ethnicity, gender, generation, and socioeconomic status.

Thus, most Brazilian States and Municipalities still display a basic programmatic flaw in explanation, prioritization, and strategic intervention with disadvantaged population groups - or those that remain vulnerable due to their living conditions and that suffer the consequences of social iniquities for their overall and oral health. The current and future possibilities for effectively impacting epidemiological indicators in oral health and meeting people's unique needs for care result from the potentiation of programmatic actions targeting such groups and individuals. Resource allocation should thus seek not only efficiency and effectiveness, but above all equity.

It is worrisome to note that this is not exactly a "new issue". Since the 1990s, numerous proponents have called for the development of the capacity to analyze the health situation and intervene in key problems and priority population groups from a territorialized perspective. Brazil would thereby expand its capacity to manage, monitor, and evaluate the SUS, with an emphasis on building health surveillance systems with actions operationalized through "intelligent mapping" of problems that affect the population at the local level (with its particular needs) and programmatic decision-making based on the best available evidence for the context under intervention. Far from being a normative design for a "given" future, programming can indeed serve to guide action in the present and future, allowing the forecasting of scenarios based on social sciences in health, epidemiology, clinical practice, 
and social control, mobilizing different actors in the arena of governability in which they interrelate in the local programming scenario.

What we are probably witnessing is a "divorce" between the academic community (with knowledge and research practices achieving levels of excellence in the thematic fields of oral health planning and epidemiology) and the world of services that continues to be shielded against "translational research". The result is relative incommunicability between institutional cultures that fail to connect in reciprocal translation of knowledge and support in the implementation of good practices.

Thus, one of the central tasks is still training for the strategic role of health programming, featuring the role of continuing education and research practices in the SUS, with closer relations between academia and services 5 . After all, what should oral health programming be (essential to the interests of the Brazilian people and the SUS) if not technical and scientific intelligence at the service of political wisdom?
1. Castiel LD, Rivera FJU. Planejamento em saúde e epidemiologia no Brasil: casamento ou divórcio? Cad Saúde Pública 1985; 1:447-56.

2. Vilasbôas ALQ, Paim JS. Práticas de planejamento e implementação de políticas no âmbito municipal. Cad Saúde Pública 2008; 24:1239-50.

3. Santos APP, Nadanovsky P, Oliveira BH. Survey of Brazilian governmental health agencies shows conflicting recommendations concerning oral hygiene practices for children. Cad Saúde Pública 2010; 26:1457-63.

4. Moysés SJ, Pucca Junior GA, Paludetto Junior M, Moura L. Avanços e desafios à Política de Vigilância à Saúde Bucal no Brasil. Rev Saúde Pública 2013; 47 Suppl 3:161-7.

5. Nunes ED, Nascimento JL, Barros NF. A questão curricular para o plano de formação em Saúde Coletiva: aspectos teóricos. Ciênc Saúde Coletiva 2010; 15:1935-43.

Submitted on 12/Mar/2014

Approved on 30/Apr/2014 